\title{
Association between serum thyroid hormone balance and thyroid volume in patients treated with levothyroxine monotherapy for hypothyroidism
}

\author{
Sawako Takahashi, Mitsuru Ito, Yuzuki Masaki, Mikiko Hada, Mizuho Minakata, Kazuyoshi Kohsaka, \\ Tomohiko Nakamura, Toshihiko Kasahara, Takumi Kudo, Eijun Nishihara, Shuji Fukata, \\ Mitsushige Nishikawa, Takashi Akamizu and Akira Miyauchi
}

Center for Excellence in Thyroid Care, Kuma Hospital, Hyogo 650-0011, Japan

\begin{abstract}
Many previous studies including ours have reported that athyreotic patients on levothyroxine $\left(\mathrm{LT}_{4}\right)$ have relatively low serum free triiodothyronine $\left(\mathrm{FT}_{3}\right)$ levels, whereas patients with large goitrous diseases often have high serum $\mathrm{FT}_{3}$ levels. Here we investigated Hashimoto thyroiditis (HT) patients on $\mathrm{LT}_{4}$ to study the relationship between thyroid volume (TV) and thyroid hormone status in hypothyroid patients on $\mathrm{LT}_{4}$. We retrospectively studied 408 euthyroid HT patients treated with $\mathrm{LT}_{4}$ for hypothyroidism; divided them as per TV and compared serum levels of free thyroxine $\left(\mathrm{FT}_{4}\right)$ and $\mathrm{FT}_{3}$ and the $\mathrm{FT}_{3} / \mathrm{FT}_{4}$ ratio in each patient group with those in euthyroid matched control group. We also evaluated the association between serum FT level and $\mathrm{FT}_{3} / \mathrm{FT}_{4}$ ratio and $\mathrm{TV}$ among $\mathrm{HT}$ patients on $\mathrm{LT}_{4}$. In patients with $\mathrm{TV}<15 \mathrm{~mL}$, serum $\mathrm{FT}_{3}$ levels were significantly lower than those in controls. In patients with TV $15-80 \mathrm{~mL}$, serum $\mathrm{FT}_{3}$ levels were equivalent to those in controls. In patients with $\mathrm{TV} \geq 80 \mathrm{~mL}$, the serum $\mathrm{FT}_{3}$ levels were significantly higher than those in controls. The serum $\mathrm{FT}_{3}$ level $(r=0.35, p<$ $0.01)$ and $\mathrm{FT}_{3} / \mathrm{FT}_{4}$ ratio $(r=0.42, p<0.01)$ showed a positive correlation with TV. TVs in HT patients on $\mathrm{LT}_{4}$ caused differences in serum thyroid hormone balance, as increasing volume increases the serum $\mathrm{FT}_{3}$ level and $\mathrm{FT}_{3} / \mathrm{FT}_{4}$ ratio. Serum thyroid hormone balance in HT patients with smaller thyroids was similar to that in athyreotic patients. Mild thyrotropin suppression with $\mathrm{LT}_{4}$ is needed to achieve normal $\mathrm{FT}_{3}$ levels in such patients.
\end{abstract}

Key words: Thyrotropin, Triiodothyronine, Levothyroxine, Hashimoto thyroiditis, Hypothyroidism

THE TWO MAJOR THYROID HORMONES in the body are triiodothyronine $\left(\mathrm{T}_{3}\right)$ and thyroxine $\left(\mathrm{T}_{4}\right)$. Approximately $20 \%$ of $\mathrm{T}_{3}$ is produced from the thyroid gland via two pathways, as follows: coupling of monoiodotyrosine and diiodotyrosine (DIT) and conversion of $\mathrm{T}_{4}$ to $\mathrm{T}_{3}$ by type 1 and type 2 iodothyronine deiodinases (D1 and D2, respectively). The remaining $80 \%$ of $\mathrm{T}_{3}$ is derived from the conversion of $\mathrm{T}_{4}$ to $\mathrm{T}_{3}$ in extrathyroidal tissues. In contrast, $100 \%$ of $\mathrm{T}_{4}$ is secreted by the thyroid gland through the coupling of two DIT moieties [1].

Some previous studies including ours have reported normal serum thyrotropin (TSH) levels associated with mildly low serum free triiodothyronine $\left(\mathrm{FT}_{3}\right)$ levels in patients on levothyroxine $\left(\mathrm{LT}_{4}\right)$ monotherapy for athyreotic or atrophic conditions after total thyroidectomy or

Submitted Aug. 24, 2020; Accepted Oct. 18, 2020 as EJ20-0542 Released online in J-STAGE as advance publication Nov. 25, 2020 Correspondence to: Mitsuru Ito, MD, Kuma Hospital, Center for Excellence in Thyroid Care, 8-2-35 Shimoyamate-Dori, Chuo-Ku, Kobe, Hyogo 650-0011, Japan.

E-mail: ito02@kuma-h.or.jp after radioiodine treatment for Graves' disease [2-5]. In addition, we have reported that the presence of the remnant thyroid tissue was associated with normal $\mathrm{FT}_{3}$ levels in patients treated with $\mathrm{LT}_{4}$ who underwent hemithyroidectomy [6] or radioiodine treatment for Graves' disease [5]. In contrast, we documented that Hashimoto thyroiditis (HT) patients with increased thyroid volume (TV) tended to present with high serum $\mathrm{FT}_{3}$ levels, low free thyroxine $\left(\mathrm{FT}_{4}\right)$ levels, and high $\mathrm{FT}_{3} / \mathrm{FT}_{4}$ ratios $[7,8]$. Thus, TV may be an important factor affecting thyroid hormonal balance, including serum $\mathrm{FT}_{3}$ levels and $\mathrm{FT}_{3} / \mathrm{FT}_{4}$ ratios.

In the present study, we investigated the thyroid hormone balance among HT patients during $\mathrm{LT}_{4}$ monotherapy for hypothyroidism who presented with a variety of TVs, and we elucidated the relationship between TV and thyroid hormone status in hypothyroid patients on $\mathrm{LT}_{4}$. 


\section{Materials and Methods}

\section{Patients}

We retrospectively identified 408 consecutive patients (379 women and 29 men) with HT from hospital medical records who visited the Kuma Hospital between January 2012 and May 2018. We based the diagnosis of HT on the presence of anti-thyroglobulin antibody ( $\mathrm{TgAb}$ ) positivity and/or anti-thyroid peroxidase antibody (TPOAb) positivity, and a heterogeneous hypoechoic pattern in a thyroid ultrasound examination.

The inclusion criteria were as follows: (1) underwent an ultrasound examination and TV was measured, (2) administered $\mathrm{LT}_{4}$ before a thyroid ultrasound examination, and (3) TSH level within the laboratory reference range $(0.3-5.0 \mu \mathrm{IU} / \mathrm{mL})$ on a thyroid ultrasound examination. The exclusion criteria were as follows: (1) follicular adenoma and thyroid malignancies, (2) thyroid dysfunction, such as Graves' disease, thyroid dyshormonogenesis, autonomously functioning thyroid nodules, or hypothyroidism, (3) administered drugs known to affect thyroid function or thyroid hormone metabolism, such as a steroids, estrogen, amiodarone, lithium, $\beta$-blockers, sucralfate, and iron or iodine-containing drugs, (4) chronic or serious diseases, such as cardiac, pulmonary, hepatic, renal, or pancreatic diseases, diabetes or hyperparathyroidism, and (5) pregnant or lactating women. In addition to the above exclusion criteria, patients who failed to achieve the target TSH levels were also excluded from the analysis.

\section{Control subjects}

Overall, 1,149 consecutive euthyroid subjects (901 women and 248 men) who were examined for possible thyroid abnormalities at the Kuma Hospital during the same period as that of patients and did not have clinical or laboratory signs of thyroid diseases served as controls. Subjects with positive TPOAb or TgAb test results or with abnormal findings on ultrasound examination were excluded. Subjects with a thyroidal nodule or a goiter (TV: men $\geq 20 \mathrm{~mL}$ and women $\geq 18 \mathrm{~mL}$ ) [9] on an ultrasound examination were also excluded. The other exclusion criteria were the same as those used for the selection of the patients. We balanced covariates including age, sex, and the measured year for choosing the control subjects for each patient group. Control subjects for each group of patients were chosen from 1,149 subjects selected earlier by 1:1 matching. This study was approved by the Ethical Committee at Kuma Hospital, and all patients gave written, informed consent.

\section{Laboratory serum tests}

For the patients who were taking $\mathrm{LT}_{4}$, blood samples were obtained in the morning after the ingestion of $\mathrm{LT}_{4}$. The patients' serum levels of $\mathrm{TSH}, \mathrm{FT}_{4}$, and $\mathrm{FT}_{3}$ were measured using a chemiluminescent immunoassay (ARCHTECT i2000; Abbott Japan, Tokyo). The intraassay coefficients of variation and the inter-assay coefficients of variation were $1.1 \%-5.0 \%$ and $1.7 \%-5.3 \%$ for the TSH assay, $2.3 \%-5.3 \%$ and $3.6 \%-7.8 \%$ for the $\mathrm{FT}_{4}$ assay, and $1.4 \%-4.2 \%$ and $2.3 \%-5.0 \%$ for the $\mathrm{FT}_{3}$ assay, respectively. The reference ranges in our hospital are 0.3-5.0 $\mu \mathrm{IU} / \mathrm{mL}$ for TSH, $0.7-1.6 \mathrm{ng} / \mathrm{dL}$ for $\mathrm{FT}_{4}$, and 1.7-3.7 pg/mL for $\mathrm{FT}_{3}$. The serum levels of $\mathrm{TgAb}$ and TPOAb were measured using an electrochemiluminescence immunoassay (ECLusys 2010; Roche Diagnostics Japan, Tokyo; normal range: $<40 \mathrm{IU} / \mathrm{mL}$ for $\mathrm{TgAb},<16$ $\mathrm{IU} / \mathrm{mL}$ for TPOAb). A TgAb level less than $40 \mathrm{IU} / \mathrm{mL}$ was regarded as $40 \mathrm{IU} / \mathrm{mL}$ and that more than 4,000 $\mathrm{IU} / \mathrm{mL}$ was regarded as $4,000 \mathrm{IU} / \mathrm{mL}$, for the purpose of statistical calculations. A TPOAb level less than 16 $\mathrm{IU} / \mathrm{mL}$ was regarded as $16 \mathrm{IU} / \mathrm{mL}$ and that more than $600 \mathrm{IU} / \mathrm{mL}$ was regarded as $600 \mathrm{IU} / \mathrm{mL}$, for the purpose of statistical calculations. TV was measured using an ultrasound, as reported previously. First, the maximum width (W), maximum thickness (T), and maximum length (L) were measured in the right lobe (r) and left lobe (1). Second, TV was calculated by the following equation: $\mathrm{TV}=0.70(\mathrm{Wr} \times \mathrm{Tr} \times \mathrm{Lr}+\mathrm{Wl} \times \mathrm{Tl} \times \mathrm{Ll})[10]$.

\section{Statistical analysis}

Grouped data are expressed as the mean \pm standard deviation or the median ( $25^{\text {th }}$ to $75^{\text {th }}$ percentiles). Group comparisons among the HT patients stratified according to TV were analyzed using the $\chi^{2}$ test (sex), TukeyKramer test, or Steel-Dwass. Treatment effects (control vs. HT patients on $\mathrm{LT}_{4}$ for hypothyroidism) were analyzed using the paired $t$-test for data with a normal distribution and the Wilcoxon signed rank test for data with a nonparametric distribution. Significance was defined as $p$-value $<0.05$ (two-sided).

\section{Results}

\section{Characteristics among the HT patient groups stratified according to $T V$}

Baseline characteristics data of the HT patients are listed in the Table 1. In the present study, all patients had normal serum TSH levels. We stratified the patients into seven groups according to their TVs, as follows: $<5 \mathrm{~mL}, 5-10$ $\mathrm{mL}, 10-15 \mathrm{~mL}, 15-20 \mathrm{~mL}, 20-50 \mathrm{~mL}, 50-80 \mathrm{~mL}$, and $\geq 80$ $\mathrm{mL}$. In the context of patients by $\mathrm{TV}, \mathrm{LT}_{4}$ doses tended to be higher in the atrophy group. There was an association between serum $\mathrm{FT}_{3} / \mathrm{FT}_{4}$ level and $\mathrm{LT}_{4}$ dose in each group with $5 \mathrm{~mL} \leq \mathrm{TV}$. In contrast, there was no correlation between $\mathrm{FT}_{3}$ level and $\mathrm{LT}_{4}$ dose (data were not shown). 
Table 1 Baseline characteristics sub grouped by thyroid volume in patients with Hashimoto's thyroiditis

\begin{tabular}{|c|c|c|c|c|c|c|c|}
\hline $\begin{array}{l}\text { Patient subgroups: } \\
(\mathrm{mL})\end{array}$ & $\begin{array}{c}\text { G1 } \\
\text { TV }<5\end{array}$ & $\begin{array}{c}\mathrm{G} 2 \\
5 \leq \mathrm{TV}<10\end{array}$ & $\begin{array}{c}\mathrm{G} 3 \\
10 \leq \mathrm{TV}<15\end{array}$ & $\begin{array}{c}\mathrm{G} 4 \\
15 \leq \mathrm{TV}<20\end{array}$ & $\begin{array}{c}\text { G5 } \\
20 \leq \mathrm{TV}<50\end{array}$ & $\begin{array}{c}\mathrm{G} 6 \\
50 \leq \mathrm{TV}<80\end{array}$ & $\begin{array}{c}\mathrm{G} 7 \\
\mathrm{TV} \geq 80\end{array}$ \\
\hline$n$ (male) & $25(1)$ & $48(7)$ & $53(4)$ & $57(5)$ & $96(6)$ & $50(1)$ & $79(5)$ \\
\hline Age (years) & $64 \pm 11$ & $62 \pm 15$ & $54 \pm 17$ & $52 \pm 17$ & $58 \pm 14$ & $61 \pm 13$ & $66 \pm 10^{\mathrm{c}, \mathrm{d}}$ \\
\hline $\mathrm{LT}_{4}$ dose ( $\mu \mathrm{g} /$ day) & $94 \pm 19$ & $80 \pm 29$ & $63 \pm 30^{\mathrm{a}}$ & $33 \pm 62^{a}$ & $67 \pm 28^{a}$ & $57 \pm 27^{a}$ & $64 \pm 29^{a}$ \\
\hline TSH $(\mu \mathrm{IU} / \mathrm{mL})$ & $\begin{array}{c}1.10 \\
(0.62-1.62)\end{array}$ & $\begin{array}{c}1.32 \\
(0.78-2.52)\end{array}$ & $\begin{array}{c}2.24^{\mathrm{a}} \\
(1.32-3.15)\end{array}$ & $\begin{array}{c}1.55 \\
(0.90-2.70)\end{array}$ & $\begin{array}{c}1.98 \\
(1.05-3.28)\end{array}$ & $\begin{array}{c}1.99^{\mathrm{a}} \\
(1.38-3.67)\end{array}$ & $\begin{array}{c}1.21^{\mathrm{ce}, \mathrm{f} f} \\
(0.63-1.90)\end{array}$ \\
\hline $\mathrm{FT}_{4}(\mathrm{ng} / \mathrm{dL})$ & $\begin{array}{c}1.16 \\
(1.13-1.23)\end{array}$ & $\begin{array}{c}1.16 \\
(1.08-1.25)\end{array}$ & $\begin{array}{c}1.08 \\
(1.02-1.20)\end{array}$ & $\begin{array}{c}1.10 \\
(1.02-1.20)\end{array}$ & $\begin{array}{c}1.06 \\
(0.95-1.21)\end{array}$ & $\begin{array}{c}0.96^{\mathrm{a}, \mathrm{b}, \mathrm{c}, \mathrm{d}} \\
(0.87-1.11)\end{array}$ & $\begin{array}{c}1.04^{\mathrm{a}, \mathrm{b}, \mathrm{d}} \\
(0.89-1.14)\end{array}$ \\
\hline $\mathrm{FT}_{3}(\mathrm{pg} / \mathrm{mL})$ & $\begin{array}{c}2.59 \\
(2.36-2.79)\end{array}$ & $\begin{array}{c}2.62 \\
(2.43-2.84)\end{array}$ & $\begin{array}{c}2.64 \\
(2.45-2.84)\end{array}$ & $\begin{array}{c}2.68 \\
(2.48-2.93)\end{array}$ & $\begin{array}{c}2.73 \\
(2.50-2.93)\end{array}$ & $\begin{array}{c}2.82^{\mathrm{a}, \mathrm{b}} \\
(2.57-3.00)\end{array}$ & $\begin{array}{c}2.92^{\mathrm{a}, \mathrm{b}, \mathrm{c}, \mathrm{d}, \mathrm{e}} \\
(2.74-3.16)\end{array}$ \\
\hline $\operatorname{TgAb}(\mathrm{IU} / \mathrm{mL})$ & $\begin{array}{c}345.0 \\
(93.7-2,962.0)\end{array}$ & $\begin{array}{c}238.4 \\
(115.1-592.3)\end{array}$ & $\begin{array}{c}345.6 \\
(123.6-672.8)\end{array}$ & $\begin{array}{c}502.5 \\
(322.9-1,026.0)\end{array}$ & $\begin{array}{c}423.5 \\
(217.7-788.5)\end{array}$ & $\begin{array}{c}418.0 \\
(272.7-561.5)\end{array}$ & $\begin{array}{c}509.3 \\
(385.2-744.7)\end{array}$ \\
\hline TPOAb (IU/mL) & $\begin{array}{c}40.9 \\
(16.0-164.4)\end{array}$ & $\begin{array}{c}64.3 \\
(16.0-226.0)\end{array}$ & $\begin{array}{c}183.9 \\
(34.4-441.1)\end{array}$ & $\begin{array}{c}160.4 \\
(29.0-354.3)\end{array}$ & $\begin{array}{c}375.6^{\mathrm{a}, \mathrm{b}} \\
(104.3-600.0)\end{array}$ & $\begin{array}{c}337.5^{\mathrm{a}, \mathrm{b}} \\
(40.9-600.0)\end{array}$ & $\begin{array}{c}214.9^{\mathrm{a}} \\
(20.7-600)\end{array}$ \\
\hline
\end{tabular}

Abbreviations: TV, Thyroid volume; TSH, thyroid stimulating hormone; $\mathrm{FT}_{4}$, free thyroxine; $\mathrm{FT}_{3}$, free triiodothyronine.

Values shown are the means \pm SD in case of normal distribution and the medians $(25-75 \%$ tile $)$ in case of nonparametric distribution. Statistical significance was analyzed by the $\chi^{2}$ test (sex), Tukey-Kramer test) or Steel-Dwass test for multiple comparisons.

${ }^{\mathrm{a}} p<0.05$, compared with G1, ${ }^{\mathrm{b}} p<0.05$, compared with $\mathrm{G} 2,{ }^{\mathrm{c}} p<0.05$, compared with G3, ${ }^{\mathrm{d}} p<0.05$, compared with $\mathrm{G} 4,{ }^{\mathrm{e}} p<0.05$, compared with G5, ${ }^{\mathrm{f}} p<0.05$, compared with G6.

\section{Serum thyroid hormone levels in HT patients stratified according to $T V$ and those in the matched euthyroid controls}

In patients with TV levels $<5 \mathrm{~mL}, 5-10 \mathrm{~mL}$, and 10 $15 \mathrm{~mL}$, the serum $\mathrm{FT}_{3}$ levels were significantly lower than those in the matched controls $(p<0.05, p<0.001, p$ $<0.05$, respectively). In patients with TV levels $15-20$ $\mathrm{mL}, 20-50 \mathrm{~mL}$, and $50-80 \mathrm{~mL}$, the serum $\mathrm{FT}_{3}$ levels were equivalent to those in the matched controls $(p=$ $0.109, p=0.111, p=0.452$, respectively). In patients with TV levels $\geq 80 \mathrm{~mL}$, the serum $\mathrm{FT}_{3}$ levels were significantly higher than those in the matched controls $(p<$ 0.05) (Fig. 1A).

In patients with TV levels $<5 \mathrm{~mL}, 5-10 \mathrm{~mL}$, and 10 $15 \mathrm{~mL}$, the serum $\mathrm{FT}_{4}$ levels were significantly higher than those in the matched controls $(p<0.05, p<0.001$, $p<0.05$, respectively). In patients with TV levels $15-20$ $\mathrm{mL}, 20-50 \mathrm{~mL}, 50-80 \mathrm{~mL}$, and $\geq 80 \mathrm{~mL}$, the serum $\mathrm{FT}_{4}$ levels were equivalent to those in matched controls $(p=$ $0.157, p=0.158, p=0.251, p=0.844$, respectively) (Fig. 1B).

In patients with TV levels $<5 \mathrm{~mL}, 5-10 \mathrm{~mL}$, and 10 $15 \mathrm{~mL}$, the serum $\mathrm{FT}_{3} / \mathrm{FT}_{4}$ ratios were significantly lower than those in the matched controls $(p<0.001$, $p<0.001, p<0.001$, respectively). In patients with TV levels $15-20 \mathrm{~mL}, 20-50 \mathrm{~mL}$, and $50-80 \mathrm{~mL}$, the serum $\mathrm{FT}_{3} / \mathrm{FT}_{4}$ ratios were equivalent to those in the matched controls ( $p=0.077, p=0.055, p=0.094$, respectively). In patients with TV levels $\geq 80 \mathrm{~mL}$, the serum $\mathrm{FT}_{3} / \mathrm{FT}_{4}$ ratios were significantly higher than those in the matched controls $(p<0.05)$ (Fig. 1C).

\section{Association between serum $\mathrm{FT}_{3}$ levels and $\mathrm{FT}_{3} / \mathrm{FT}_{4}$ ratios and TV in $\mathrm{HT}$ patients treated with $\mathrm{LT}_{4}$ for hypothyroidism}

The correlations between serum $\mathrm{FT}_{3}$ levels and $\mathrm{FT}_{3} / \mathrm{FT}_{4}$ ratios and TV in $\mathrm{HT}$ patients treated with $\mathrm{LT}_{4}$ for hypothyroidism were evaluated. The serum $\mathrm{FT}_{3}$ levels showed a positive correlation with TV $(r=0.35$, $p<0.01$; Fig. 2A). The serum $\mathrm{FT}_{3} / \mathrm{FT}_{4}$ ratios also showed a positive correlation with TV $(r=0.42, p<$ 0.01; Fig. 2B).

\section{Discussion}

In the present study, in patients with small or normal TVs $(<15 \mathrm{~mL})$, the serum $\mathrm{FT}_{3}$ levels significantly lower than those of controls. Thus, these data were similar to those from previous studies of athyreotic patients on $\mathrm{LT}_{4}$ who underwent total thyroidectomy [2] or atrophic thyroid patients on $\mathrm{LT}_{4}$ who underwent radioiodine treatment for Graves' disease [5]. In contrast, in patients with slight or moderate goiter (TV, 20-80 mL), serum $\mathrm{FT}_{3}$ levels were equivalent to those of the controls. These data were consistent with those from previous studies of patients on $\mathrm{LT}_{4}$ who underwent a hemithyroidectomy [6] or of a certain volume of thyroid gland (TV $>10 \mathrm{~mL}$ ) patients on $\mathrm{LT}_{4}$ who underwent radioiodine treatment for 

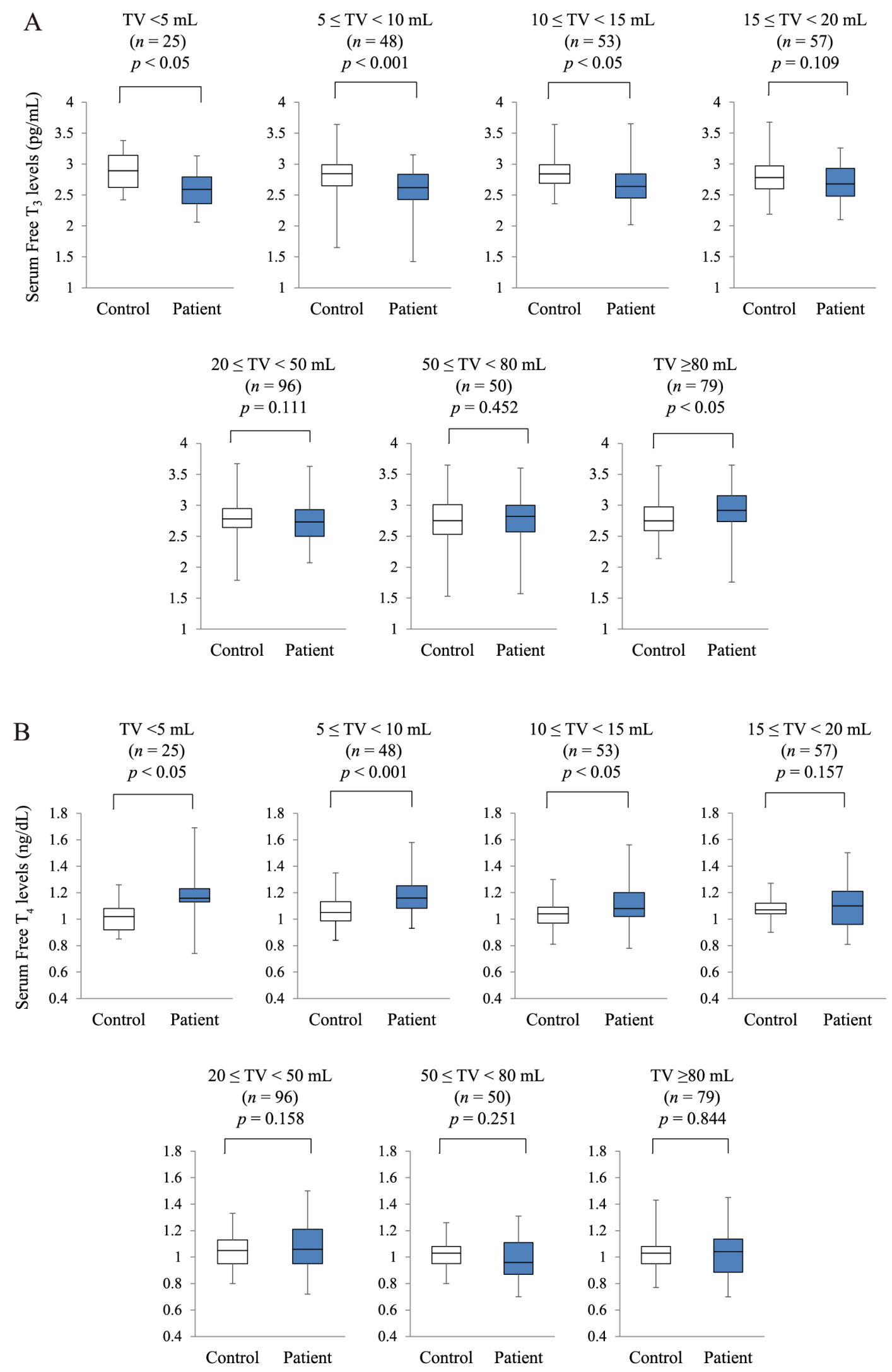

Fig. 1 Serum levels of $\mathrm{FT}_{3}(\mathrm{~A}), \mathrm{FT}_{4}(\mathrm{~B})$ and $\mathrm{FT}_{3} / \mathrm{FT}_{4}(\mathrm{C})$ in patients with Hashimoto thyroiditis $(\mathrm{HT})$ and in euthyroid controls with intact thyroid matched by age, sex, and the measured year. The HT patients were divided into seven groups stratified by TV levels. The top, bottom, and middle lines of the boxes correspond to the $75^{\text {th }}, 25^{\text {th }}$, and $50^{\text {th }}$ percentiles (median), respectively. The whiskers extend from the minimum to the maximum. TV, Thyroid volume; $\mathrm{FT}_{3}$, free triiodothyronine; $\mathrm{FT}_{4}$, free thyroxine; $\mathrm{TSH}$, thyrotropin. 

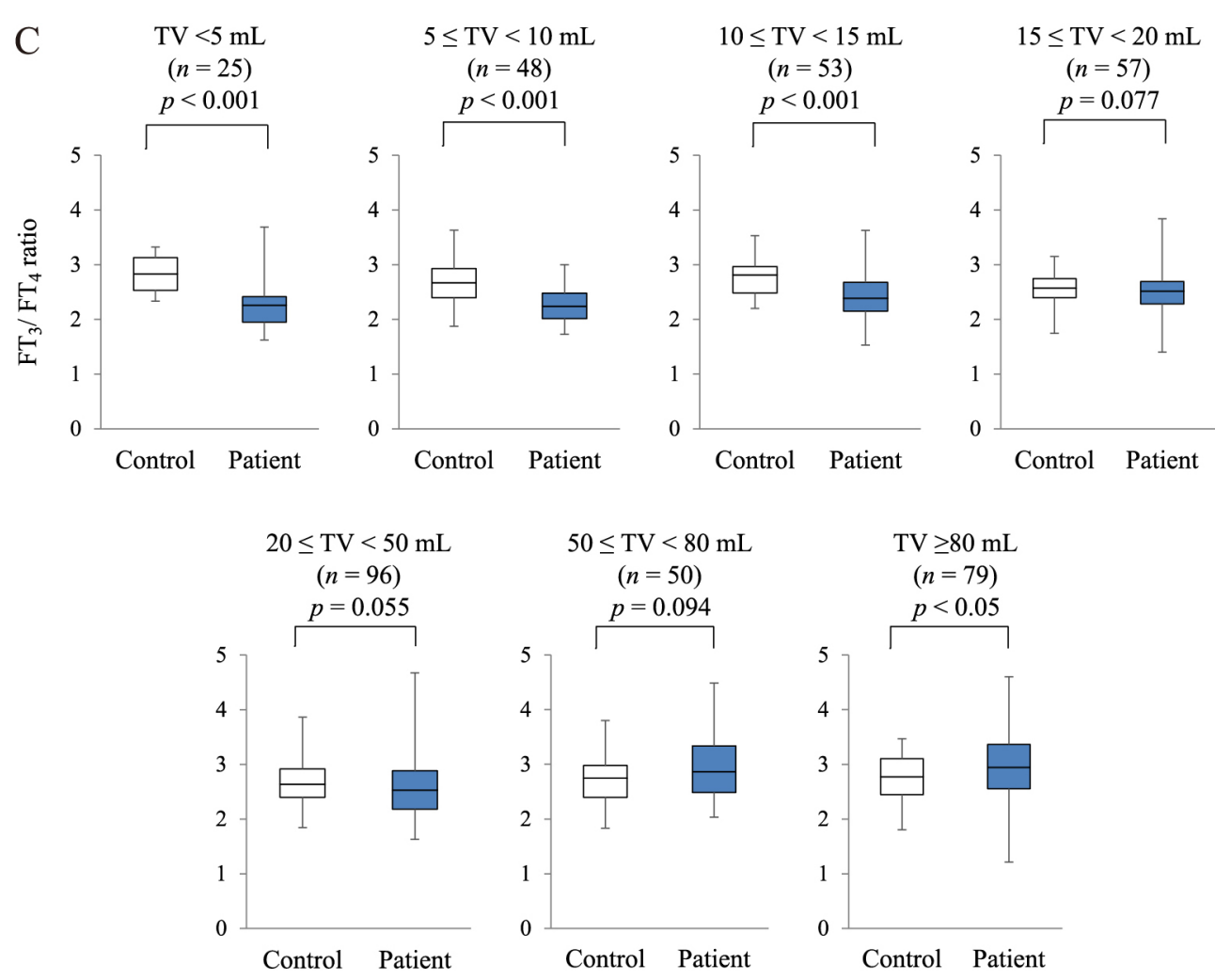

Fig. 1 Cont.
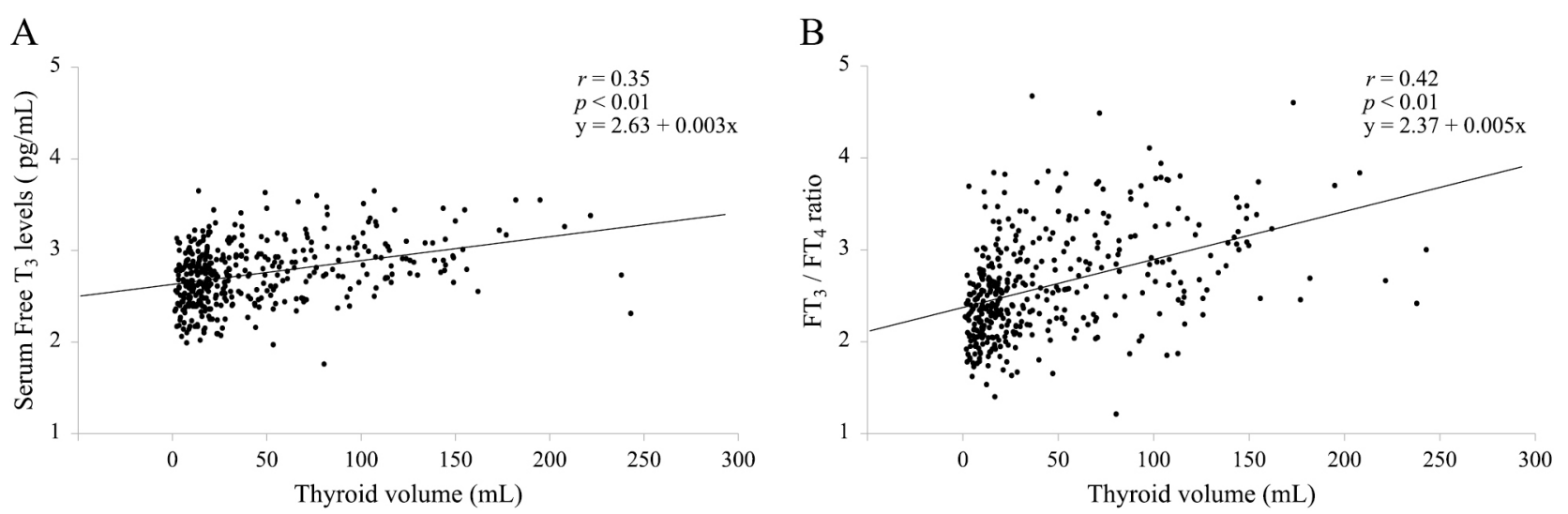

Fig. 2 (A) Association between serum free triiodothyronine and thyroid volume using the Pearson's correlation coefficient test among Hashimoto thyroiditis patients. (B) Association between serum free triiodothyronine/free thyroxine ratio and thyroid volume using the Pearson's correlation coefficient test among Hashimoto thyroiditis patients.

Graves' disease [5]. These findings suggest that the reason underlying the decreased serum $\mathrm{T}_{3}$ levels in such patients is the lack of intra-thyroidal $\mathrm{T}_{3}$ production caused by atrophy or loss of the thyroid gland.

There are two types of deiodinases (D1 and D2) that contribute to $\mathrm{T}_{3}$ production. The serum $\mathrm{FT}_{3} / \mathrm{FT}_{4}$ ratio reflects the activity of the deiodinase enzyme, which converts $\mathrm{T}_{4}$ to $\mathrm{T}_{3}$ by $5^{\prime}$-deiodination [11]. Maia et al. estimated that $\mathrm{D} 2$ is the major contributor of extrathyroi- dal $\mathrm{T}_{3}$ production in euthyroid subjects [12]. While, Hoermann et al. indicated that $\mathrm{LT}_{4}$-treated patients with a post-interventional lower residual volume $(<5 \mathrm{~mL})$ have significantly reduced deiodinase activity and lowered $\mathrm{T}_{3}$ levels, as compared with patients with a higher residual TV [13]. Such atrophic or athyreotic patients have reduced thyroidal deiodinase activity and $\mathrm{T}_{3}$ production from the thyroid gland, resulting in a relatively low serum $\mathrm{FT}_{3}$ level and $\mathrm{FT}_{3} / \mathrm{FT}_{4}$ ratio [6]. It is necessary to 
clarify whether D1 and/or D2 activity in the thyroid tissues of such patients contributes to the patients' lower serum $\mathrm{FT}_{3}$ level and serum $\mathrm{FT}_{3} / \mathrm{FT}_{4}$ ratios.

Our present study revealed that HT patients with large goiter ( $\mathrm{TV} \geq 80 \mathrm{~mL}$ ) had relatively high serum $\mathrm{FT}_{3}$ levels and a high $\mathrm{FT}_{3} / \mathrm{FT}_{4}$ ratio. We also demonstrated a positive correlation between the serum $\mathrm{FT}_{3} / \mathrm{FT}_{4}$ ratio and $\mathrm{TV}$, findings consistent with those from our previous report $[7,8]$. Elevation of thyroidal deiodinase activity, predominantly that of $\mathrm{D} 2$ activity, was reported as the cause of serum $\mathrm{FT}_{3}$ level and $\mathrm{FT}_{3} / \mathrm{FT}_{4}$ ratio elevation in several large goitrous thyroid diseases, such as those involving thyroglobulin gene mutations, McCune-Albright syndrome, and $\mathrm{T}_{3}$-predominant Graves' disease [14-16]. Recently, we reported the elevation of thyroidal deiodinase activity (especially D2 activity) at the posttranslational level in seven HT patients with large goiters; this increase in enzyme activity may be responsible for the relatively high serum $\mathrm{FT}_{3} / \mathrm{FT}_{4}$ ratio observed in these patients [7]. We also demonstrated a positive correlation between deiodinase activities and TV [8]. These findings suggest that intra-thyroidal $\mathrm{T}_{3}$ production by increased deiodinase activity is a substantial factor influencing the relatively high serum $\mathrm{T}_{3}$ levels in HT patients with large goiters. These may also be related to higher $\mathrm{LT}_{4}$ doses when the goiter was small and lower $\mathrm{LT}_{4}$ doses when the goiter was large in the present study. These results suggest that thyroid tissue capacity plays a significant role in the physiological process of $\mathrm{T}_{3}$ homeostasis in humans; this contention fits well with the results from the present study.

In atrophic or normal thyroid size patients on $\mathrm{LT}_{4}$, patients with normal TSH levels had relatively low serum $\mathrm{FT}_{3}$ levels. The question arises as to whether such a patient is in a euthyroid condition. In the athyreotic patients with normal TSH and low $\mathrm{T}_{3}$ levels, the relatively higher serum $\mathrm{T}_{4}$ levels that accompany $\mathrm{LT}_{4}$ monotherapy seems to result in normal $\mathrm{T}_{3}$ receptor occupancy and TSH in pituitary thyrotrophs. In contrast, in peripheral tissues, the relatively higher serum $\mathrm{T}_{4}$ levels could impair intracellular $\mathrm{T}_{3}$ production via downregulation of a D2 pathway [17]. In fact, an animal study has shown that $\mathrm{LT}_{4}$ alone administered in thyroidectomized rats at doses to normalize plasma TSH levels does not normalize $\mathrm{T}_{3}$ contents in some tissues [18]. In another study of rats, Werneck et al. reported that a combination of high serum $T_{4}$ and low serum $T_{3}$ levels during $T_{4}$ monotherapy in rats had consequences of thyroid hormone action, as reflected in the brain, liver, and skeletal muscle, all of which exhibited indications of hypothyroidism despite normal serum TSH level [17]. In a previous study conducted in humans, we compared biochemical markers reflecting thyroid function before and after thyroidectomy.
Therefore, the biochemical markers suggest that the patients with mildly suppressed TSH levels were closest to euthyroid, whereas those with normal TSH levels were mildly hypothyroid [19]. Recently, in a large $\mathrm{LT}_{4}{ }^{-}$ treated population with normal serum TSH, participants exhibited lower serum $\mathrm{T}_{3}$ levels and differed in terms of both objective and subjective measures [20]. In addition, a meta-analysis performed by McAninch et al. showed that serum total cholesterol and low-density lipoprotein levels remain high in $\mathrm{LT}_{4}$-treated euthyroid patients in meta-analysis [21].

The symptoms of thyroidal dysfunction have also been reported by several prior studies. Recently, we compared reported subjective symptoms reflecting thyroid function before and after thyroidectomy. Therefore, the symptoms suggest that the patients with mildly suppressed TSH levels were closest to euthyroid, whereas those with normal TSH levels were mildly hypothyroid [22]. Larisch et al. conducted a retrospective longitudinal study including patients with differentiated thyroid carcinoma on $\mathrm{LT}_{4}$. Therefore, $26 \%$ of patients expressed hypothyroid and $9.7 \%$ hyperthyroid complaints at any one visit. Hypothyroid symptoms correlated well with $\mathrm{FT}_{3}$ levels and were observed when TSH levels were below the reference range [23]. The American Thyroid Association stated in its guidelines that for the treatment of hypothyroidism such as in athyreotic patients, there is insufficient evidence of benefit to recommend $\mathrm{LT}_{4}$ treatment for achieving low-normal TSH values or high-normal $\mathrm{T}_{3}$ values [24]. Overall, the presence of biochemical markers and symptoms of thyroid function in animal and human studies of $\mathrm{LT}_{4}$-treated athyreotic conditions suggests that patients with normal TSH might not be euthyroid in all tissues, and mild TSH suppression with $\mathrm{LT}_{4}$ might be needed to achieve euthyroidism.

In the present study, the patients on $\mathrm{LT}_{4}$ with large goitrous thyroid had relatively high serum $\mathrm{FT}_{3}$ levels. It is unclear currently whether relatively high serum $\mathrm{FT}_{3}$ in such patients presents with thyrotoxicosis. The clinical significance of the relative high serum $\mathrm{FT}_{3}$ levels in patients with large goiter should be evaluated in the future.

There are some limitations in the present study. First, the limited number of study patients, unequal group distribution, and single time point reduced the internal validity of the study. Second, we did not evaluate biochemical markers and the symptoms reflecting thyroid function. In addition, we did not evaluate echo pattern (low or normal) of HT patients. Studies including measures of these clinical parameters are thus needed to clarify the best method of managing HT patients' thyroid function on $\mathrm{LT}_{4}$.

$\mathrm{LT}_{4}$ has been considered the standard of care for treatment of hypothyroidism for many years. $\mathrm{LT}_{4}$ 
replacement therapy has three main goals: (i) provide resolution of the patients' symptoms and hypothyroid signs, including biological and physiologic markers of hypothyroidism, (ii) achieve normalization of serum TSH with improvement in thyroid hormone concentrations, and (iii) avoid overtreatment [24]. This study suggests that one of the three main goals has a pitfall. Patients with hypothyroidism due to HT are treated with $\mathrm{LT}_{4}$ and live in a chronic condition of abnormal thyroid hormone status for their lives. Therefore, even if the thyroidal dysfunction may be subtle, its long-term effects cannot be overlooked. We analyzed a large number of HT patients on $\mathrm{LT}_{4}$ and demonstrated that their TVs caused differences in serum thyroid hormone balance. The patients with normal TSH levels had relatively high serum $\mathrm{FT}_{3}$ levels and $\mathrm{FT}_{3} / \mathrm{FT}_{4}$ ratios as their goiter size increased. Thus, serum low $\mathrm{FT}_{3}$ levels in $\mathrm{HT}$ patients on $\mathrm{LT}_{4}$ with relatively small thyroid were consistent with those in athyreotic patients on $\mathrm{LT}_{4}$, and serum high $\mathrm{FT}_{3}$ levels in HT patients on $\mathrm{LT}_{4}$ with relatively large thyroid were consistent with those in patients with large goitrous thyroid disease. In the former, the possibility of mild hypothyroidism has been suggested, and mild TSH suppression with $\mathrm{LT}_{4}$ may be needed to achieve normal $\mathrm{FT}_{3}$ levels. The clinical significance of the latter is for further study. Our findings may provide novel information that could assist in the management of a large number of patients treated with $\mathrm{LT}_{4}$ for hypothyroidism.

\section{Acknowledgments}

Author contributions: M. Ito constructed the study design. S. Takahashi analyzed the data. The other coauthors contributed by administering patient care.

\section{Disclosure Statement}

The authors declare no competing financial interests.

\section{References}

1. Pilo A, Iervasi G, Vitek F, Ferdeghini M, Cazzuola F, et al. (1990) Thyroidal and peripheral production of 3,5,3'triiodothyronine in humans by multicompartmental analysis. Am J Physiol 258: E715-E726.

2. Ito M, Miyauchi A, Morita S, Kudo T, Nishihara E, et al. (2012) TSH-suppressive doses of levothyroxine are required to achieve preoperative native serum triiodothyronine levels in patients who have undergone total thyroidectomy. Eur J Endocrinol 167: 373-378.

3. Gullo D, Latina A, Frasca F, Le Moli R, Pellegriti G, et al. (2011) Levothyroxine monotherapy cannot guarantee euthyroidism in all athyreotic patients. PLoS One 6: e22552.

4. Hoermann R, Midgley JE, Giacobino A, Eckl WA, Wahl HG, et al. (2014) Homeostatic equilibria between free thyroid hormones and pituitary thyrotropin are modulated by various influences including age, body mass index and treatment. Clin Endocrinol (Oxf) 81: 907-915.

5. Ito M, Kawasaki M, Danno H, Kohsaka K, Nakamura T, et al. (2019) Serum thyroid hormone balance in levothyroxine monotherapy-treated patients with atrophic thyroid after radioiodine treatment for Graves' disease. Thyroid 29: $1364-1370$.

6. Ito M, Miyauchi A, Kang S, Hisakado M, Yoshioka W, et al. (2015) Effect of the presence of remnant thyroid tissue on the serum thyroid hormone balance in thyroidectomized patients. Eur J Endocrinol 173: 333-340.

7. Harada A, Nomura E, Nishimura K, Ito M, Yoshida H, et al. (2019) Type 1 and type 2 iodothyronine deiodinases in the thyroid gland of patients with huge goitrous Hashimoto's thyroiditis. Endocrine 64: 584-590.

8. Kawasaki M, Ito M, Danno H, Kousaka K, Nakamura T, et al. (2019) The association between thyroid hormone balance and thyroid volume in patients with Hashimoto thyroiditis. Endocr J 66: 763-768.

9. Kitaoka M, Suzuki S (ed) (2016) Thyroid Ultrasound - A guidebook for diagnosis and management (3rd edition). Japan Association of Breast and Thyroid Sonology. Nankodo, Tokyo, Japan (In Japanese).

10. Murakami Y, Takamatsu J, Sakane S, Kuma K, Ohsawa N (1996) Changes in thyroid volume in response to radioactive iodine for Graves' hyperthyroidism correlated with activity of thyroid-stimulating antibody and treatment outcome. J Clin Endocrinol Metab 81: 3257-3260.

11. Bianco AC, Salvatore D, Gereben B, Berry MJ, Larsen PR (2002) Biochemistry, cellular and molecular biology, and physiological roles of the iodothyronine selenodeiodinases. Endocr Rev 23: 38-89.

12. Maia AL, Kim BW, Huang SA, Harney JW, Larsen PR (2005) Type 2 iodothyronine deiodinase is the major source of plasma T3 in euthyroid humans. J Clin Invest 115: 2524-2533.

13. Hoermann R, Midgley JE, Larisch R, Dietrich JW (2015) Integration of peripheral and glandular regulation of triiodothyronine production by thyrotropin in untreated and thyroxine-treated subjects. Horm Metab Res 47: 674-680.

14. Kanou Y, Hishinuma A, Tsunekawa K, Seki K, Mizuno Y, et al. (2007) Thyroglobulin gene mutations producing defective intracellular transport of thyroglobulin are associated with increased thyroidal type 2 iodothyronine deiodinase activity. J Clin Endocrinol Metab 92: 1451-1457.

15. Celi FS, Coppotelli G, Chidakel A, Kelly M, Brillante BA, et al. (2008) The role of type 1 and type 25 '-deiodinase in the pathophysiology of the 3,5,3'-triiodothyronine 
toxicosis of McCune-Albright syndrome. J Clin Endocrinol Metab 93: 2383-2389.

16. Ito M, Toyoda N, Nomura E, Takamura Y, Amino N, et al. (2011) Type 1 and type 2 iodothyronine deiodinases in the thyroid gland of patients with 3,5,3'-triiodothyroninepredominant Graves' disease. Eur J Endocrinol 164: 95 100.

17. Werneck de Castro JP, Fonseca TL, Ueta CB, McAninch EA, Abdalla S, et al. (2015) Differences in hypothalamic type 2 deiodinase ubiquitination explain localized sensitivity to thyroxine. $J$ Clin Invest 125: 769-781.

18. Escobar-Morreale HF, Obregón MJ, Escobar del Rey F, Morreale de Escobar G (1995) Replacement therapy for hypothyroidism with thyroxine alone does not ensure euthyroidism in all tissues, as studied in thyroidectomized rats. J Clin Invest 96: 2828-2838.

19. Ito M, Miyauchi A, Hisakado M, Yoshioka W, Ide A, et al. (2017) Biochemical markers reflecting thyroid function in athyreotic patients on levothyroxine monotherapy. Thyroid 27: 484-490.
20. Peterson SJ, McAninch EA, Bianco AC (2016) Is a normal TSH synonymous with "euthyroidism" in levothyroxine monotherapy? J Clin Endocrinol Metab 101: 49644973.

21. McAninch EA, Rajan KB, Miller CH, Bianco AC (2018) Systemic thyroid hormone status during levothyroxine therapy in hypothyroidism: a systematic review and metaanalysis. J Clin Endocrinol Metab 103: 4533-4542.

22. Ito M, Miyauchi A, Hisakado M, Yoshioka W, Kudo T, et al. (2019) Thyroid function related symptoms during levothyroxine monotherapy in athyreotic patients. Endocr $J$ 66: 953-960.

23. Larisch R, Midgley JEM, Dietrich JW, Hoermann R (2018) Symptomatic relief is related to serum free triiodothyronine concentrations during follow-up in levothyroxinetreated patients with differentiated thyroid cancer. Exp Clin Endocrinol Diabetes 126: 546-552.

24. Jonklaas J, Bianco AC, Bauer AJ, Burman KD, Cappola $\mathrm{AR}$, et al. (2014) Guidelines for the treatment of hypothyroidism. Thyroid 24: 1670-1751. 